\title{
International intangible cultural heritage policy in the neighbourhood: an assessment and case study of Indonesia
}

\section{International intangible cultural heritage policy in the neighbourhood: an assessment and case study of Indonesia}

\author{
UNESCO's heritage policies are one of the most extensive global drivers of \\ landscape and cultural transformation and investment. In response to complaints \\ about Western and object-focussed bias in World Heritage, a push within \\ UNESCO generated a new convention and a new category of heritage: intangible \\ cultural heritage (ICH). Maligned by academic critics, it has nonetheless been an \\ incredibly widespread program internationally with over 170 nation-states signed \\ up to its convention and subject to its obligations. This article provides an \\ assessment of the geographical reach and impact of UNESCO's intangible \\ cultural heritage program, and, through a case study in Indonesia, analysis of its \\ most successful (according to the Indonesian Directorate of Culture) program for \\ the production of batik cloth. Through the case study, I assess the impact of the \\ intangible cultural heritage policy in Indonesia at different levels and for different \\ groups, the scales it has enabled, and its impact on historical batik landscapes.
}

Keywords: intangible cultural heritage; UNESCO; Indonesia; scale; landscape; batik

By the mid-1990s, the Convention Concerning the Protection of the World Cultural and Natural Heritage, commonly known as the World Heritage Convention, was being strongly criticised. Academics were pointing out the effects of the western bias in the rationale of heritage management in other parts of the world (Byrne 1991, Titchen 1996), and in UNESCO itself the World Heritage List was criticised as geographically biased towards Europe, categorically biased towards religious buildings and old towns, religiously biased towards Christianity, and having a class bias towards 'elitist' forms of architecture (UNESCO 1994). The subject of this paper is the response to these criticisms that has elicited the most widespread international support: the Convention for the Safeguarding of the Intangible Cultural Heritage (henceforth, the CSICH) and its 
concept of intangible cultural heritage (ICH).

A broad definition of ICH sets the scope for the CSICH:

the practices, representations, expressions, knowledge, skills - as well as the instruments, objects, artefacts and cultural spaces associated therewith - that communities, groups and, in some cases, individuals recognize as part of their cultural heritage. This intangible cultural heritage, transmitted from generation to generation, is constantly recreated by communities and groups in response to their environment, their interaction with nature and their history, and provides them with a sense of identity and continuity, thus promoting respect for cultural diversity and human creativity. For the purposes of this Convention, consideration will be given solely to such intangible cultural heritage as is compatible with existing international human rights instruments, as well as with the requirements of mutual respect among communities, groups and individuals, and of sustainable development. (Article 2.1)

In contrast to the sites, monuments and landscapes favoured by World Heritage, ICH covers a range of practices that are not strictly defined. UNESCO's 'domains' provide a guide to what is generally considered to be ICH: oral traditions and expressions; performing arts; social practices, rituals and festive events; knowledge and practices concerning nature and the universe; and traditional craftsmanship. ${ }^{i}$ Led by Asian nation-states and with strong support from nation-states within Africa, South America and continental Europe, the CSICH has spread both the concept of ICH and national ICH lists across the globe. However, ICH too has its critics.

The effects and desirability of the CSICH has been the subject of much academic attention and debate. ${ }^{\text {ii }}$ The most common critical thrust in the academic literature is best captured by Michael Brown's (2005, p. 48) critique that the CSICH brings a bureaucratic, information management approach to preserving cultural heritage, and that, while it may bring more attention to $\mathrm{ICH}$, "one struggles to imagine how it will protect cultures as living, dynamic systems". Like other authors (Kreps 2009), 
Brown's desire to support an, or perhaps any, initiative that draws attention to the status and priorities of neglected minority and developing country cultures and groups is pitted against his desire to find more effective mechanisms that address the causes of cultural decline. In 2005, then Director of the Smithsonian Center for Folklife and Cultural Heritage, Richard Kurin (2012), replied to another of Brown's (2012) critical essays. ${ }^{\mathrm{ii}}$ As someone whose institution regularly engaged with both the communities and practices targeted by the $\mathrm{CSICH}$ and national governments, Kurin took a more pragmatic position. While being critical of the use of heritage lists, he made the point that the UNESCO intervention is another in a continuing series of events and changes that cause cultures to adapt and react, and that it is a step towards more informed, holistic and just state engagement "so that culture retains its vitality and dynamism" (2012, p. 100).

Kurin's point that cultures have and will always adapt to new circumstances is made by other commentators (Alivizatou 2012). However, the CSICH should be distinguished from other international impacts on cultural practices (such as international trade agreements or education initiatives) as it expressly aims to safeguard a set of these practices through influencing heritage policy. In 2005, Kurin's support was based on what could happen in the upcoming years, rather than empirical evidence. Similarly to Brown, Christina Kreps assesses the CSICH as unlikely to support Indigenous peoples' heritage presentation and practices to maintain their cultures (Indigenous curation), but also ultimately holds off on judgement: "We will not know the impact of the Convention until after it has been fully ratified, put into practice, and we have the chance to carry out empirical studies on actual projects" (2005, p. 7). Now, over ten years since the CSICH came into force and with 174 nation-states currently signed up, the impacts and implications of the convention should be assessible. 
This article takes on this challenge through a case study of Indonesia's engagement with the CSICH, supplemented with secondary research on listings in other countries. First I provide an overview of the CSICH's creation, characteristics and controversies. Second, I briefly review the signatories and the list itself to assess the outcomes of its attempts at a broad representation. Third, I undertake a case study of Indonesia with a focus on the listing of batik in 2009 focussing on the listing process, its broad impact, and the subsequent changes to a batik producing area. Batik is a "traditional handcrafted textile ... made by applying dots and lines of hot wax to cloth using a copper pen-like instrument (canthing tulis), or copper stamps (canthing cap), as a resist to hand-dyeing" (Directorate of Culture 2009, p. 1).

While a comprehensive assessment of the $\mathrm{CSICH}$ would require comparative analysis across countries and types of $\mathrm{ICH}$, the use of secondary research and detailed case study data provides the basis for some limited conclusions and I hope will contribute towards a broader conversation about the assessment, functioning and purpose of the $\mathrm{CSICH}$. As a top-down initiative, assessing the impact of ICH programs requires an awareness of its impacts at different levels for different individuals and groups. As I have argued elsewhere (Jones et al. 2016), one of heritage's most attractive features is its utility in arguing for new scales, including new connections and flows. Indeed one of the most interesting consequences of the batik listing due to its success is its impact on historical landscapes due to its effects on the livelihoods of batik-producing communities. ${ }^{\text {iv }}$

The concept of ICH, while now widespread, has been controversial in heritage research, and is connected to a broader issue of how to conceive of the physical and symbolic dimensions of heritage. John Tunbridge, Greg Ashworth and Brian Graham (2013, p. 367), in their reflective essay on A Geography of Heritage (Graham et al. 
2000), insist that "all heritage is intangible" and that the concept of ICH itself is an unhelpful categorical separation of the physical from the symbolic. However, many of critical heritage studies' key texts including their own have emphasised symbolic and discursive processes as the foundation of understanding contemporary heritage, in part as a corrective to the emphasis on objects in heritage management (Byrne 2008). Hence Laurajane Smith (2006, p. 13), in her influential book Uses of heritage, can make the claim that "There is no such thing as "heritage."” Rodney Harrison and Deborah Bird Rose's (2010, p. 264) critique of discursive approaches to heritage argues this understanding "replicates the mind-matter dualism in suggesting that the material world has no values or meanings in and of itself." The relational and the physical are entwined together, leading to their call for a "dialogical" approach where heritage is understood as bound collaboratively by sentient beings. Following Harrison and Bird Rose (2010) and Tim Ingold (2011), my position is that heritage, like landscapes, is shaped through flows sustained by relationships (including with and between plants, animals, materials and physical forces) and, as Don Mitchell (2013) demonstrates, at times can be held the same through radical changes in how flows are sustained. Since the separation of the tangible and intangible in heritage is impossible, my analysis seeks to understand how the ICH program and its division of heritage has broadly influenced the people and places affected by its implementation.

\section{A history of the CSICH}

The events that preceded the ratification of the $\mathrm{CSICH}$ have been recounted numerous times (Bortolotto 2010, Harrison 2013) including detailed analysis from people intimately involved in its creation (Aikawa-Foure 2009, Blake 2009, Aikawa 2004), so only a brief description is provided here. While UNESCO discussions on the protection of folklore date back to the 1950s (Kurin 2004), the formal effort to create an 
international instrument is located in the reactions to the Convention Concerning the Protection of the World Cultural and Natural Heritage in 1972 (in particular by Bolivia (Aikawa 2004)). Debates and UNESCO expert meetings about intangible heritage continued across the 1980s and culminated in the 1989 adoption of the Recommendation on the Safeguarding of Traditional Culture and Folklore. This nonbinding agreement was ultimately found to have little impact (Skounti 2009, Blake 2009). UNESCO initiated a number of programs across the 1990s that increased its engagement with ICH, including an ICH program in 1992 and the Living Human Treasures system in 1993.

The push for an "instrument" (Aikawa 2004, Aikawa-Foure 2009) that would engage with ICH intensified at this time, in particular through an assessment of the World Heritage List that criticised amongst other things its geographical bias towards Europe and its focus on architectural value and gaps in its recognition of "living culture" (UNESCO 1994). In 1998 UNESCO created the Proclamation of Masterpieces of the Oral and Intangible Heritage of Humanity, initiated by threats to performance practices within the Jemaa el Fna Square in Marrakesh, Morocco (Schmitt 2008). It also provided a focus for intangible cultural heritage initiatives and was implemented as a pilot study (Aikawa-Foure 2009). The appointment of the Director of the World Heritage Centre, Japanese national Koiichiro Matsuura, to the position of DirectorGeneral of UNESCO in 1999 gave added impetus to the push for a convention to address ICH. A series of expert meetings and considerations by UNESCO member states took place from 2001, ${ }^{\mathrm{v}}$ and the CSICH was adopted by the UNESCO General Conference in 2003. The CSICH entered into force on 20 April 2006 after thirty states ratified the convention. 
While the $\mathrm{CSICH}$ can be read as part of an international trend towards greater diversity in culture and heritage, these trends were driven by the actions of specific groups and institutions. UNESCO has since early in its inception been a forum where countries have addressed systemic or historical disparities (significantly but not exclusively between developing and developed countries), and consequently is an institution that has addressed such issues.$^{\mathrm{vi}}$ However, this should not conceal the important role of particular actors. Lyn Meskell (2012, 2015, Meskell and Brumann 2015) has demonstrated the importance of analysis of the relationships and influence of different actors over world heritage, and CSICH actors demonstrate similar behaviours (Aikawa-Foure 2009). ${ }^{\text {vii }}$ Japan has and continues to be particularly active in the area of heritage: its sponsorship made UNESCO's intangible cultural heritage program possible in the 1990s, greatly assisted the Masterpieces program and funded the development of the CSICH; a Japanese Director-General prioritised the creation of the convention at a time when there was not decisive support in the Executive Board (Aikawa 2004, Aikawa-Foure 2009); it established heritage legislation in 1950 (revised in 1954) that included intangible heritage; and it had been using heritage as a form of soft power, particularly in southeast Asia. Both Japan (in their Asia-Pacific Cultural Centre for UNESCO (ACCU) established in 1971) ${ }^{\text {viii }}$ and Korea (in the new International Information and Networking Centre for Intangible Cultural Heritage in the Asia and Pacific Region (ICHCAP) established in 2011) ${ }^{\text {ix }}$ worked with nations in Asia to establish their ICH programs after the $\mathrm{CSICH}$ came into force. The states that distanced themselves from the CSICH were all developed countries with broadly similar approaches to heritage; Australia, Canada, the UK, Switzerland and the USA abstained from the vote to ratify the convention.

The convention establishes two UNESCO lists and a register has evolved from its text. 
These are: the Representative List of the Intangible Cultural Heritage of Humanity (henceforth, the Representative List); the List of Intangible Heritage in Need of Urgent Safeguarding (henceforth the Urgent Safeguarding List) that targets ICH state parties and UNESCO agree require urgent attention; and the Register of Best Safeguarding Practices consisting of activities that best reflect the principles of the $\mathrm{CSICH}$. The resulting mechanisms simultaneously replicates some elements of the WH Convention, in particular its use of lists that has proven very popular with nation-states, while hugely expanding the ambit of heritage.

The greatest impacts of the CSICH are generated through the obligations the convention places on signatory nation-states. The CSICH emphasises the need for the involvement of practitioners and communities in safeguarding practices, particularly the process of entering ICH onto the lists. Practitioner and community involvement is transformed into concrete requirements through the operational directives (Blake 2009). Providing a role for practitioners and communities is an innovation in this area of international law, but poses difficulties in its application and monitoring (Seeger 2009). A related requirement is that the nomination includes a programme to safeguard the nominated ICH. The type and extent of the engagement and programs determines who benefits from ICH initiatives, and the extent and characteristics of local outcomes relative to bureaucratic activities. A second requirement was for the creation of national intangible cultural heritage lists in states that joined the convention. This is a mammoth bureaucratic task that drives the concept of ICH into many more locations and practices. Assessing the detail and impacts of these obligations is the most important focus and contribution of this article.

Even though the CSICH establishes a Representative List of the Intangible Cultural Heritage of Humanity, there is still a lack of clarity about what a 
"representative list" represents. Unlike World Heritage, the CSICH does not include quality as a criterion for listing. The critics of using the criterion of quality argued that it would be difficult to apply, be biased towards developed nations, and was not in keeping with the activity of safeguarding (Hafstein 2009). The term "representative list" has over time been interpreted to refer to the purpose of listing: to promote greater visibility of intangible cultural heritage "as representatives of intangible cultural heritage" in order to "showcase the diversity of intangible heritage" and promote safeguarding (UNESCO 2012, p. 7). Perhaps the exclusion of quality as a criterion is more important than the confused statements on what inclusion actually reflects beyond official recognition. However, the use of the term "representative list" has implications for prioritising what is listed. Rule 34 of the Operational Guidelines prioritises states that do not have elements subscribed, for multinational nominations, and for the List of Intangible Cultural Heritage in Need of Urgent Safeguarding, and the best safeguarding practices. Funding limitations and the number of signatories to the CSICH also play a part in geographical representativeness, which is clearly prioritised in the Operational guidelines over representativeness of types or characteristics of $\mathrm{ICH}$, or the innovative, inclusive and/or democratic use of ICH. While the next section connects to these issues through an assessment of the characteristics of the current list, questions about its impact are assessed in the case study of Indonesia.

\section{A brief review of the current "representative" list}

While a comprehensive assessment (particularly of what is listed) would require a longer analysis, a short summary of the nation-states who are parties to the CSICH and the Representative List provides an indication of the signatories and listed $\mathrm{ICH}$. As a nation-state cannot list $\mathrm{ICH}$ without being a signatory to the $\mathrm{CSICH}$, the timing of ratification is an important factor in what is listed. Another factor is the capacity of 
UNESCO to assess nominations. The USA's withdrawal of funding from UNESCO in 2011 after UNESCO accepted Palestine as a full member put great financial pressure on the program that was already constrained by the increasing number of nominations. While the operational guidelines have since their first iteration in 2008 held to the principle of geographical diversity, early signatories had many more opportunities to have their ICH listed than later signatories. Inscription takes two years and in 2016 there was a surplus of 119 nominations dating back to 2010, although the surplus has reduced since 2012, indicating a greater degree of coordination. UNESCO now attempts to process approximately fifty nominations a year. ${ }^{\mathrm{x}}$

Turning to geographical spread, there is evidence the many of the Asian and African states who pushed for the CSICH have not been able to progress many listings with the exceptions of larger states in East Asia. While over $98 \%$ of African states are signatories, their listings were only $17.6 \%$ of the 355 items on the Representative List in 2016 (see Table 1). Despite the absence of the USA and Canada, Europe and North American states constituted $33.5 \%$ of all listings, and five of the ten states with the most listings were European. The lowest percentage of CSICH signatories is from Asia and Oceania $(58.0 \%)$. While these states had listed a high proportion of the items on the Representative List (30.2\%), over half of these items (67 or $17.1 \%$ of all items listed) were from three countries in East Asia: China, Japan and the Republic of Korea (See Table 2). Due to these three countries, Asia and Oceania had the highest number of listings per state (4.1) while Latin America and the Caribbean (1.7) and Africa (1.3) had the lowest. Larger and richer states appear to have a greater capacity to prepare and advocate for nominations. The power of these states and the initial activity of China, Japan and Korea inevitably created a geographical bias that requires mechanisms to 
correct. The requirement that attention be given to states with the least number of nominations may not be enough.

While an analyses of the items on the Representative List requires its own article in order to adequately deal with issues of classification and the complexities of these categories, it is worth noting that public controversies over the listings often focussed on the listed items rather than issues of inclusion and exclusion. Wide spread ridicule, such as what followed listing of the "Gastronomic meal of the French,"xi threatens to undermine UNESCO and other heritage efforts. However, the vast majority of listings are in the areas of performing arts and social practices, rituals and festive events. These types of listings are now generally uncontroversial as UNESCO's definition of ICH has become widespread. There are also eight (by my count) culinary items listed, and Jacobs (2014, p. 101) points to "unwritten rules" such as no electricity and no "European elite culture". However, the content of the list gives little away about the politics of listing, which requires attention to specific circumstances at lower levels.

Table 1: Signatory states to the CSICH by geographical region*

Table 2: The nine nation-states with the most items on the Representative List*

\section{Assessing the impact of the CSICH: an Indonesian case study}

Blake's (2014, p. 293) "seven year review" of the CSICH, assesses the national level impact "in large part" using reports presented by States Parties. While the reports indicate that national policies are being articulated to the $\mathrm{CSICH}$, they do not provide proof, as Blake concludes, of "a fundamental shift in the pre-existing relationships between state authorities and local communities, which both challenges the authority of the former and promises to respect more effectively the cultural rights of the latter" (2014, p. 299). Analysis of such changes requires analysis of both broader historical 
shifts, and the specific conditions in each country, particularly if we are to understand the use of the CSICH and draw conclusions on its impact. For instance, Jacobs (2014) locates the $\mathrm{CSICH}$ as an extension of five centuries of elite and governmental engagement with popular culture to tame and educate populations. While Jacobs focusses on Europe, the circumstances of each region and country will inflect their adoption of ICH.

There have also been many studies of the impact of the CSICH in different countries and the diversity of outcomes that, it would appear, connect more with specific conditions than the goals of the convention. McLaren (2011) characterised use of ICH in the Lower Yangzi Delta as an evolving element of a gentrification process. The National Museum in Vanuatu selectively employs UNESCO CSICH discourses to achieve local goals (Alivizatou 2012). Two recent assessments, of traditional medicine in South Africa (Riordan and Schofield 2014) and the Mediterranean diet (Pfeilstetter 2014) investigate the multilevel arrangements and possibilities that the CSICH generates. In both cases, an established popular industry engages (Pfeilstetter 2014) or is engaged (Riordan and Schofield 2014) with ICH concepts in order to establish new scales and modes of operation, with broader benefits for practitioners, consumers and businesses. Pfeilstetter (2014, p. 227) locates the impact of the CSICH in these relationships: "It is the relation between the global and the local institutions that should be described for every specific case of ICH items of Humanity." Assessing the impact of the CSICH in Indonesia is therefore a grounded study of how the CSICH fits into a longer history of engagement with traditional popular culture, and if the contemporary relationships it generates provide positive outcomes for a range of groups, in particular practitioners and communities of listed $\mathrm{ICH}$. 


\section{Indonesia and the CSICH}

As the objective of the research was to assess the CSICH nomination process and subsequent operations of the programs and their relationships to developments in the listed practices, the research method that I pursued was archival research in both Indonesia in the archive of the Indonesian National Commission for UNESCO and UNESCO Paris (in 2013), targeted interviews (following Dunn 2010) and participant observation (Kearns 2010). As there were too many practices for each to be assessed, I used a case study approach (Baxter 2010) focussing on the successful nomination of batik. Batik was chosen after an initial assessment because of the impact of the nomination relative to the other practices. The archival research addressed all of the listed items initially, before focusing on batik. The interviews were undertaken on two fieldtrips: the first to Jakarta in 2012 and the second to Yogyakarta, Solo and Semarang in Central Java in 2015 (see Table 3). The participant observation of the impacts of the growth in batik sales and tourism to batik neighbourhoods was undertaken on this fieldtrip. The sample of 14 interviews focussed on individuals involved in the nomination process in Jakarta and heritage and batik organisations and producers in Yogyakarta, Solo and Semarang. The interviews were all recorded, then revised into notes while on the fieldtrip, and reviewed again at the time of writing. ${ }^{\text {xii }} \mathrm{My}$ interpretation of the data was greatly assisted by my experience undertaking research in Indonesia over a 16 year period, with a focus on cultural policy and heritage issues.

Table 3: Interviews undertaken for this research

The Indonesian state has enthusiastically embraced UNESCO’s ICH program. Indonesia successfully submitted two items to the Masterpieces of the Oral and Intangible Heritage of Humanity program in 2003 (Wayang Puppet Theatre) and 2005 
(Indonesian kris), ${ }^{\text {xiii }}$ and became a signatory to the CSICH on 15 October 2007.

Indonesia now has five elements on the Representative List, two elements on the Urgent Safeguarding List, and one element registered as a Best Safeguarding Practice (see Table 4). ${ }^{\text {iv }}$ It was a member of the Intergovernmental Committee for the Safeguarding of Intangible Cultural Heritage from 2010 to 2014. While this activity alone makes it a good case study, it is enhanced by the significant cultural policy changes of this period.

Table 4: Items listed by Indonesia on UNESCO's Masterpieces (until 2008) and Intangible Cultural Heritage Lists

Like all cultural practices, regional arts and performances in Indonesia have been subject to the political and economic relations of the different ages (Jones 2013). Dutch colonial rule often preserved ruling families, whose presence helped to legitimise Dutch rule as well as court arts (Pemberton 1994), and cultural research in the early twentieth century was intended to assist colonial administration (Gouda 1995). Colonial and Japanese occupation era initiatives in archaeology also created connections that have international legacies that endure until today, in particular since the 1970s through international assistance within UNESCO's world heritage program (Bloembergen and Eickhoff 2015). Regional performance increased in political importance following the start of national governance and began to receive increasing recognition from 1956 (Jones 2013, p. 98). National culture was defined in the 1945 Constitution, which returned in a surge of cultural nationalism under Sukarno in 1959, as the "high cultural achievements in regions throughout Indonesia" supplemented by "new materials from foreign culture" (Jones 2013, p. 97). During the Sukarno government of 1957 to 1959 , cultural organisations affiliated with political parties, particularly LEKRA (Cultural Institute of the People) affiliated with the Indonesian 
Communist Party, increasingly interacted directly with traditional artists to implement their version of Sukarno's cultural policy.

When the political left was eliminated in the pogroms of 1965 to 1967 , performances of regional arts with affiliations to LEKRA halted and only returned with military or state patronage in the 1970s (Jones 2013, pp. 138-142). During Suharto's New Order regime, culture was articulated in relation to the state's pursuit of accelerated development: culture should both be shaped to support development, and be protected from the negative side effects of development. Regional arts bore the brunt of state attention, and were forced: to incorporate state-defined development messages, to avoid any political topics or discussion, and to undergo a broad process of bureaucrat-defined "improvement" that included shortening performance time, removal of elements considered immoral or contradictory to the official goals of development, and the insertion of an aesthetics of "respectability" (Yampolsky 1995). While the aesthetic changes were driven by a middle-class reform agenda linked to the urban culture of the political powerful and therefore had strong continuities with LEKRA (McVey 1986), the censure of political acts was new and the oil boom of the 1970s gave the New Order state the resources to implement a national cultural policy. By 1998, over 74,000 people, spread across every province, district and sub-district, were employed under the supervision of the national Directorate of Culture in Jakarta to implement this normative and antidemocratic cultural policy agenda (Jones 2013, pp. 177-180).

The command culture model of cultural management that focussed on regional arts, while challenged by the rise of mass popular culture in the 1990s, began to break down in the aftermath of the Asian Financial Crisis and the resignation of Suharto in 1998. Two shifts in particular were important. First, cultural policy was realigned from 
an affiliation with education to an affiliation with tourism. Second and more importantly, cultural policy was one of a number of policy areas decentralised in 2002, devolving control of the cultural bureaucracy from the national to the provincial and district levels (Jones 2013, pp. 185-190). The raison d'être of the national bureaucracy was challenged by both these decisions. From an educational function, culture was aligned with the economic goals of tourism and regional development. Furthermore, from providing oversight of a centralised national cultural program, the Directorate of Culture needed to redefine its functions within the new policy framework where a broader swathe of regional cultural practices fit within the framework of national culture. This is the context in which the $\mathrm{CSICH}$ entered Indonesian cultural policy. Heritage designation is attractive because of the opportunities it offers for the rearticulation of scales, and the flows of status and resources they promise (Jones et al. 2016). The Masterpieces and ICH listings provided opportunities for the national bureaucracy to define their relationship as coordinating the variety of different players required to prosecute a heritage listing in association with the Coordinating Ministry for People's Welfare. ${ }^{\mathrm{xv}}$ For instance, a discussion of the construction of a "cultural map" (peta budaya) to meet the national list criteria in order to progress the batik listing attracted representatives of the Indonesian Chamber of Commerce and Industry (KADIN), UNESCO, the Coordinating Ministry for People's Welfare, Department of Trade, the Mayor of Pekalongan (a city that was investing in batik tourism), museums, and from a number of batik organisations (Anon. 2009). ${ }^{\mathrm{xi}}$ KADIN sponsored the nomination of batik. ICH initiatives also enable international connections; Japan funded three workshops (via UNESCO) on how to make lists (Interview A1), and the training was attended by China, Japan and South Korea. This reconfiguration of the national level for coordination rather than control of heritage was made possible 
because of the effectiveness of the Indonesian National Committee for UNESCO (INCU), and in particular its Chair, Arief Rachman. Rachman has been very effective at promoting UNESCO programs to Ministers and working with UNESCO's Jakarta Office (Interview A5), and was holding this position in 2016 at the age of 73.

While the New Order era approach to cultural policy survived into the Reform era, decentralisation and democratic elections encouraged the growth of a variety of cultural policy approaches that differed geographically, across time and between genres (Jones 2013, pp. 181-202). Boonstra (2015, p. 174) argues that the listing of wayang into the Masterpieces program was "a continuation of New Order discourse and power relations" due to its: continued focus on aesthetics and standardisation, continued use of New Order era cultural nationalism, and the maintenance of New Order cultural management power structures. However, this listing in 2003 was the first after the resignation of Suharto, less than a year after decentralisation, and wayang has a strong, national administrative structure unusual for regional art forms. Was the limiting cultural nationalism Boonstra identifies present and limiting for other cultural practices that are now registered on CSICH lists?

Batik has its own path through these shifts, and historically benefitted from cultural nationalism through its strong association with Indonesian traditions and handicraft in the twentieth century. While a reference to 'batick' is first found on a bill of lading for cloth shipped to the Netherlands in 1641, trade in brightly coloured cloth was common for both local markets and as presents between envoys of earlier kingdoms (Hitchcock and Nuryanti 2000b, pp. xxii-xxiii). Batik cloth design differs between regions, reflecting their history and market demand for different patterns, two of which can be seen in figures 1 and 2 (Kerlogue 2004). While local markets have always been important (including a strong Chinese influence in some regions like the north coast of 
Java), colonialism brought new elements to batik design for Europeans, and tourism has also influenced batik design in the twentieth century (Hitchcock and Nuryanti 2000a). A key innovation in the 1840s was the shift from drawing the wax resist onto fabric (tulis) and using stamps (cap) as this enabled batik to compete with cheaper imports. Other important innovations were improved cloths, which made more intricate patterns possible, and chemical dies, which reduced production times (2000). An important change brought after independence in the 1950s was the promotion of 'Batik Indonesia' where popular colour schemes were combined with courtly designs from Central Java, allowing batik to overcome its historical royal and hierarchical use, allowing batik to be associated with Indonesian nationalism. Now, as noted by Sekimoto (Sekimoto 2000), the commercial value of batik is tied to the attraction of traditional art, handicraft and cultural heritage even while it is the product of commercial innovation and diversification in response to shifting political and economic relationships over many centuries.

\section{INSERT FIGURE 1 NEAR HERE}

\section{INSERT FIGURE 2 NEAR HERE}

My starting place for assessing the listings is the choice of ICH. When asked why Indonesian politicians seek UNESCO listings, INCU Chair Arief Rachman said that "it was like winning a medal at the Olympics" (Interview A6), while batik producers drew attention to the chance for widespread promotion (Interview C1). Many of the listings have been in response to perceived affronts from Malaysia. The Balinese dance Pendet appeared on a Malaysian tourism television commercial in 2009, triggering a string of accusations from Indonesia that started with the Malaysian national anthem and went on to include wayang kulit, the kris, batik, angklung and the dance reog Ponorego (Chong 2012, Clark and Pietsch 2014). With the exception of the 
Malaysian national anthem and reog Ponorego, the items in dispute have all now been accepted for inclusion on ICH heritage lists (some before and some after 2009 as detailed in Table 3) as Indonesian heritage. The CSICH therefore is also a new front for nationalist cultural politics between neighbours whose colonial era boundaries were previously porous, often until the present. ${ }^{\text {xvii }}$ It is not coincidental that disputed Malay ICH began in 2006 when Indonesia signed the CSICH (Clark and Pietsch 2014, p. 78). The two other practices listed are based in the most eastern provinces of Papua (noken) and most western province of Aceh (saman), which both had or have strong independence movements. ${ }^{\text {xviii }}$ Other reasons for pursuing listings are to increase the Indonesian economy, foreign income (Wahyudin 2009) and Indonesian's interest in ICH practices.

While not in the spirit of the CSICH, cultural nationalism does not necessarily derail the effects of a nomination process. Blake $(2009,2014)$ points out that the obligations for consultation are a novel and innovative element in international law. Indonesia's consultation was described by a key bureaucrat as "like a research project" (Interview A3) where the datafields of the form is turned into a survey that is administered to community members, collated within the Directorate of Culture into a draft nomination, then run through line by line in a verification seminar. Batik was the nomination with the highest public profile. The involvement of KADIN and the Batik Museum in Pekalongan (itself connected to KADIN and a newly created tourism destination) increased business and public interest in the nomination. Fieldwork for batik took place in six cities, there were four verification seminars and 14 revisions, which contrasts with the two seminars for noken and angklung where the entire process took three weeks (Interview 3A). Seminars took place in the same locations as the communities of practitioners. 
The batik nomination document itself, unlike Boonstra (2015) observes for Wayang, focusses on the diversity of locations and influences on batik, technical aspects, and the effects of competition from cheaper factory-made printed fabric (Directorate of Culture 2009). The key initiative in the nomination document was to work with and support existing organisations, primarily through the creation of the Indonesian Batik Community Forum (MASBATIK), in their efforts to safeguard batik. The nomination process elicited a second successful nomination for the Best Safeguarding Practices (through a visit from a UNESCO official) of Education and training in Indonesian batik ${ }^{\mathrm{xix}}$ that celebrates the efforts of the Pekalongan Batik Museum to educate school children about batik's manufacture, history and uses. At the international level, there was some horse-trading over support for batik, with South Korea seeking support to create an ICH Centre, and Mexico asked for support for its candidature in the Intergovernmental Council of UNESCO's International Hydrological Program (Wahyudin 2009). Batik's successful inscription on the Representative List was announced on 2 October 2009.

While evidence for MASBATIK activities is scarce, the listing of batik had a much greater impact than any of the other listings. This success was due to Indonesian President Yudhoyono's declaration of National Batik Day to coincide with inscription, and encouraging civil servants to wear batik on Fridays. Following a Malaysian initiative (Clark and Pietsch 2014, p. 79), National Batik Day initiated a shift in office ware then casual ware across Indonesia that has revived the batik industry, which had been in decline since the deregulation of the textiles industry by Suharto in the early 1970s (Clark and Pietsch 2014, p. 86). The capacity of batik to benefit from this kind of promotion has been noted within the national bureaucracy, with a 2010 presentation comparing wayang, kris and batik noting that "Batik is easier to assist and use because 
it is widely used and flexible in it application" and therefore "can be used for a variety of products" in comparison with kris or wayang (Anon. 2010). This success assisted with the reconfiguration of the national level in cultural policy. The nomination process most benefitted the bureaucracy in that it defined its role and justified its existence through the creation of relationships with industry, practitioners, international partners and politicians. The increasing interest in heritage listings since 2002 should be linked to decentralisation and the new coordinating function now emphasised by the national cultural apparatus.

However, this overlooks the most important set of impacts on the batik making community that were not considered within the nomination document or subsequent programs: the impacts of economic success on batik producing neighbourhoods (kampung batik). In order to consider these impacts, our focus needs to be on the historical process through which clusters in batik neighbourhoods have been created and maintained. Batik are home based interconnected industries that have developed over centuries in close geographical proximity and are linked by communalities, which in turn creates a cultural landscape that is now attractive to outsides for both tourism and location branding of batik products (Handayani et al. 2012, Hitchcock and Nuryanti 2000a). There are close links in batik neighbourhoods between economic independence, community networks, cultural practices and the Javanese built form. Often factories are co-located with vernacular Javanese limasan houses, so the living and working spaces are shared (Handayani et al. 2012, Setyoningrum et al. 2015). While I undertook fieldwork in Kauman and Laweyan in Solo, Central Java, I focus on Laweyan here.

Laweyan was established in 1546 as the first industrial cluster for cotton textiles, and had a semi-independent relationship to the Mataram kingdom because of their 
economic success (Handayani et al. 2012). This independence has become an identity marker for Laweyan, with a prominent local batik manufacturer stating that "200 years ago Laweyan was isolated, so they worked out how to make money in order to protect their independence" (Interview C1). They became mass producers of batik during the Dutch colonial period with the invention of stamp batik. In 1930, there were 230 batik enterprises in Laweyan. However, following the deregulation of the Indonesian textile market in the 1970s, the entry of foreign printed fabrics, and changing fashions, only 10 enterprises were operating in 2003. In 2004, a group of Laweyan residents formed the Laweyan Batik Neighbourhood Development Forum (Forum Pengembangan Kampung Batik Laweyan) ${ }^{\mathrm{xx}}$ began to encourage local people to restart batik businesses. Their focus has shifted over the years from promotion, to production, to facilities and planning, including for more tourism in Laweyan itself (Interview C1). The Forum has been an important advocate to the state and international researchers and buyers, and for knowledge sharing. In 2011 there 70 batik entrepreneurs in Laweyan (Handayani et al. 2012, p. 16).

The impact of the return of batik following the activities of the Forum from 2004 and the 2009 listings has been profound for Laweyan. There has been economic growth following a thirty year period of economic downturn, establishing a boom-bustboom cycle similar to that needed for the creation of tourist-historic cities and exerting similar pressures on historic landscapes (Ashworth and Tunbridge 2000). Indeed new factories have entered to take advantage of the Laweyan brand (see Figure 3), new houses have introduced modern styles into the neighbourhood (see Figure 4), and the increasing number of tourists visiting have led to new outlets being built into the walls of compounds (see Figure 5). Hence the absence of strong heritage regulations within the batik neighbourhoods, while benefitting the local businesses, requires strong 
community organisation and, in the absence of strong heritage regulations, will undermine the experiences that tourists are seeking when they visit the batik neighbourhoods.

Figure 3: The new factory on the right can be contrasted with a traditional factory on the left (2012) Photograph by Tod Jones.

Figure 4: A new house here sits next to traditional houses inside the Laweyan neighbourhood (2012). Photograph by Tod Jones.

Figure 5: An outlet store built into the wall of a batik compound in Laweyan (2012). Photograph by Tod Jones.

\section{Conclusion}

The case study of batik indicates the difficulty of assessing whether the CSICH protects "cultures as living, dynamic systems" (Brown 2005, p. 48) as living dynamic systems adjust to new relations and therefore always "safeguard" themselves in that they transfer "knowledge, skills and meaning" within these new networks if they are useful. A more appropriate assessment is to look at what new relations and opportunities the CSICH opens up and their effects on existing relations, and in particular the new scales that are proposed by different alignments of groups. This should always begin with an assessment of the cultural policy history, approach and goals of the state. This is necessarily postcolonial in the case of Indonesia as the popular culture targeted by the $\mathrm{CSICH}$ was shaped through the colonial period and by postcolonial relations in the independence periods, just as popular culture in Europe has been shaped by the governmental programs of elites (Jacobs 2014). A distinctly national use of the CSICH is the divisive cultural nationalism of competition between nations. While this use is not in keeping with the spirit of the $\mathrm{CSICH}$, cultural nationalism is important to 
understanding how the $\mathrm{CSICH}$ has functioned in Indonesia, reinforcing national identity and impacting its relationship with Malaysia. However, a more important dynamic in Indonesia was how the CSICH presented an opportunity to assist in the redefinition of the scale of cultural policy because it coincided with a period of cultural policy change. The growth of heritage listings cannot be separated from the redefinition of the relations between cultural policy levels, particularly for the national level. The most salient element in the nomination process is the relationships that the $\mathrm{CSICH}$ enables between institutions and the coordinating role of the national state. The 'heritage' label provides access to domestic and foreign states, NGOs and businesses that open up opportunities, access, resources and obligations for these groups and the practitioners and cultural communities of the targeted practice.

The nation-state, as the coordinator, will always benefit from these new relations. The question then becomes the extent to which the practitioners and relevant cultural communities can engage to make use of and benefit from these new sets of relations. The Indonesian case study indicates that industrial-traditional practices, like batik, culinary products (Pfeilstetter 2014) and traditional medicine (Riordan and Schofield 2014) are best placed to engage with the state, listing process, and the opportunities created by this new set of relations. The smaller, regional cultural practices listed in Indonesia, particularly where there are only a small number of performers in a limited geographical area, appear to experience little impact after the elation of listing. "Safeguarding" in this model is aligned with regional economic development; a stated goal of the Indonesian state. Finally, there is the issue of the problems of success, particularly its spatial manifestations in the very spaces targeted for conservation. While nobody should deny the residents the opportunity to improve their houses and businesses, an adequate planning regime with sufficient community 
control and consultation needs to be in place as a prerequisite of the listing. While such an outcome may have been unexpected in Indonesia before the batik listing, now the spatial changes of success are clear. Much as has been suspected by the commentators (Brown 2005, Kreps 2005, Kurin 2004), the CSICH has not supported the fragile heritage presentation and practices of minority groups in Indonesia, but it is an excellent tool for reviving industrial-traditional practices with a widespread distribution network and strong representation. Such programs have the potential to assist the livelihoods of millions. Perhaps livelihoods, and not cultural maintenance, should be the measure of the CSICH. 


\section{Bibliography}

Aikawa-Foure, N., 2009. From the proclamation of masterpieces to the Convention for the Safeguarding of Intangible Cultural Heritage. In: Smith, L. and Akagawa, N. eds. Intangible Heritage. Oxon: Routledge, 13-44.

Aikawa, N. 2004. An Historical Overview of the Preparation of the UNESCO International Convention for the Safeguarding of the Intangible Cultural Heritage. Museum International, 56(1-2), 137-149.

Alivizatou, M., 2012. Intangible heritage and the museum. Walnut Creek, CA.: Left Coast Press.

Anon., 2009. Laporan pertemuan pembahasan peta budaya Indonesia, 4-5 Februari 2009. Jakarta: Direktorat Kebudayaan.

Anon., 2010. Pengelolaan wayang, keris dan batik. Jakarta: Direktorat Jenderal Nilai, Budaya, Seni dan Film.

Ashworth, G. J. and Tunbridge, J. E., 2000. The tourist-historic city: retrospect and prospect of managing the heritage city. Oxford, UK: Elsevier Science.

Barke, M. and Parks, J. 2016. An inevitable transition: the erosion of traditional vernacular building forms in the Alpujarras, southern Spain. Journal of Cultural Geography, 33(2), 133-160.

Baxter, J., 2010. Case studies in qualitative research. In: Hay, I. ed. Qualitative Research Methods in Human Geography. 3rd ed. Melbourne: Oxford University Press, 81-98.

Blake, J., 2009. UNESCO's 2003 convention on intangible cultural heritage: the implications of community involvement in 'safeguarding'. In: Smith, L. and Akagawa, N. eds. Intangible Heritage. Oxon: Routledge, 45-73.

Blake, J. 2014. Seven Years of Implementing UNESCO's 2003 Intangible Heritage Convention--Honeymoon Period or the "Seven-Year Itch"? International Journal of Cultural Property, 21(3), 291-304.

Uighur Gatherings Make U.N. Culture List, Year. Directed by Block, M. In: NPR: All Things Considered. 16 November.

Bloembergen, M. and Eickhoff, M., 2015. Decolonizing Borobudur: moral engagements and the fear of loss. In: Legêne, S., Purwanto, B. and Schulte Nordholt, H. eds. Sites, bodies and stories: imagining Indonesian history. Singapore NUS Press, 33-66.

Boonstra, S., 2015. Defining wayang as heritage: standardization, codification and institutionalization. In: Legêne, S., Purwanto, B. and Schulte Nordholt, H. eds. Sites, bodies and stories: imagining Indonesian history. Singapore NUS Press, 159-198.

Bortolotto, C., 2010. Globalising intangible cultural heritage? Between international arenas and local appropriations. In: Labadi, S. and Long, C. eds. Heritage and Globalisation. Oxon: Routledge, 97-114.

Brown, M. 2005. Heritage trouble: recent work on the Protection of intangible cultural property. International Journal of Cultural Property, 5(1), 40-61.

Brown, M. 2012. Safeguarding the Intangible. Museum Anthropology Review, 6(2), 9397.

Byrne, D. 1991. Western hegemony in archaeological heritage management. History and Anthropology, 5, 269-276. 
Byrne, D., 2008. Heritage as social action. In: Fairclough, G. J., et al. eds. The heritage reader. New York: Routledge, 149-173.

Chong, J. W. 2012. "Mine, Yours or Ours?": The Indonesia-Malaysia Disputes over Shared Cultural Heritage. Sojourn: Journal of Social Issues in Southeast Asia, 27(1), 1-53.

Clark, M. A. and Pietsch, J., 2014. Indonesia-Malaysia relations : cultural heritage, politics and labour migration. Oxfordshire, UK: Routledge.

Directorate of Culture, 2009. Nomination for inscription on the Representative List in 2009 (Reference No. 00170) [Batik nomination document]. Paris:

Intergovernmental Committee for the Safeguarding of the Intangible Cultural Heritage, UNESCO.

Dunn, K., 2010. Interviewing. In: Hay, I. ed. Qualitative Research Methods in Human Geography. 2nd ed. Melbourne: Oxford University Press, 79-105.

Gouda, F., 1995. Dutch culture overseas: colonial practice in the Netherland Indies, 1900-1942. Amsterdam: Amsterdam University Press.

Graham, B., Ashworth, G. J. and Tunbridge, J. E., 2000. A Geography of Heritage: Power, Culture and Economy. London: Arnold.

Hafstein, V. T., 2009. Intengible heritage as a list. From masterpieces to representation. In: Smith, L. and Akagawa, N. eds. Intangible Heritage. Oxon: Routledge, 93111.

Handayani, K. N., et al. 2012. Vitality of urban industrial batik clusters in Surakarta City and its implication on tourism industry. Journal of Architecture and Urban Design, 22(July), 11-20.

Harrison, R., 2013. Heritage: critical approaches. Oxon: Routledge.

Harrison, R. and Bird Rose, D., 2010. Intangible heritage. In: Benton, T. ed. Understanding heritage and memory. Manchester: Manchester University Press and Open University, 238-276.

Hitchcock, M. and Nuryanti, W., eds., 2000a. Building on Batik: the Globalization of a Craft Community. Burlington, USA Ashgate.

Hitchcock, M. and Nuryanti, W., 2000b. Introduction. In: Hitchcock, M. and Nuryanti, W. eds. Building on Batik: the Globalization of a Craft Community. Burlington, USA Ashgate, xxii-xxxi.

Ingold, T., 2011. Being alive: essays on movement, knowledge and description. London and New York: Routledge.

Jacobs, M. 2014. Bruegel and Burke were here! Examining the criteria implicit in the UNESCO paradigm of safeguarding ICH: the first decade. International Journal of Intangible Cultural Heritage, 9, 99-118.

Jones, T., 2013. Culture, Power, and Authoritarianism in the Indonesian State. Cultural Policy across the Twentieth Century to the Reform Era. Leiden: Brill.

Jones, T., Jones, R. and Hughes, M. 2016. Heritage designation and scale: a World Heritage case study of the Ningaloo Coast. International Journal of Heritage Studies, 22(3), 242-260.

Kearns, R. A., 2010. Knowing seeing? Undertaking observational research. In: Hay, I. ed. Qualitative Research Methods in Human Geography. 3rd ed. Melbourne: Oxford University Press, 241-258.

Kerlogue, F., 2004. Batik design, style and history. London and New York: Thames and Hudson.

Kreps, C., 2005. Indigenous Curation as Intangible Cultural Heritage: Thoughts on the Relevance of the 2003 UNESCO Convention. Theorising Cultural Heritage. Washington D.C.: Smithsonian Center for Folklife and Cultural Heritage. 
Kreps, C., 2009. Indigenous curation, museums and intangible cultural heritage. In:

Smith, L. and Akagawa, N. eds. Intangible Heritage. Oxon: Routledge, 193-208.

Kurin, R. 2004. Safeguarding Intangible Cultural Heritage in the 2003 UNESCO Convention: a critical appraisal. Museum International, 56(1-2), 66-77.

Kurin, R. 2012. Tangible Progress: A Response to "Safeguarding the Intangible" by Michael F. Brown. Museum Anthropology Review, 6(2), 98-101.

Lincoln, Y. and Guba, E., 1985. Naturalistic inquiry Beverly Hills, CA: Sage.

McLaren, A. E. 2011. Eco-sites, Song Traditions and Cultural Heritage in the Lower Yangzi Delta. Asian Studies Review, 35(4), 457-475.

McVey, R. T., 1986. The wayang controversy in Indonesian communism. In: Hobart, M. and Taylor, R. H. eds. Context, meaning and power in Southeast Asia. Ithaca: Southeast Asia Program, Cornell University, 21-51.

Meskell, L. 2012. The rush to inscribe: Reflections on the 35th Session of the World Heritage Committee, UNESCO Paris, 2011. Journal of Field Archaeology, 37(2), 145-151.

Meskell, L. 2015. Transacting UNESCO World Heritage: gifts and exchanges on a global stage. Social Anthropology, 23(1), 3-21.

Meskell, L. and Brumann, C., 2015. UNESCO and New World Orders. In: Meskell, L. ed. Global heritage: a reader. Chichester, UK: Wiley Blackwell, 22-42.

Miller, T. and Yudice, G., 2002. Cultural policy. London: Sage.

Mitchell, D. 2013. Labour's geography and geography's labour: California as an (anti)revolutionary landscape. Geografiska Annaler: Series B, Human Geography, 95(3), 219-233.

Murphy, C., 2001. Immaterial civilisation. Atlantic Monthly. 20.

Pemberton, J., 1994. On the subject of 'Java'. Ithaca: Cornell University Press.

Pfeilstetter, R. 2014. Heritage entrepreneurship. Agency-driven promotion of the Mediterranean diet in Spain. International Journal of Heritage Studies, 21(3), 215-231.

Post, C. W. 2013. Heritage, amenity, and the changing landscape of the rural American West. Journal of Cultural Geography, 30(3), 328-355.

Riordan, A. and Schofield, J. 2014. Beyond biomedicine: traditional medicine as cultural heritage. International Journal of Heritage Studies, 21(3), 280-299.

Robertson, I. J. M. 2015. Hardscrabble Heritage: The Ruined Blackhouse and Crofting Landscape as Heritage from below. Landscape Research, 40(8), 993-1009.

Sayare, S., 2010. Unesco Hails French Food, Oil Wrestling And Flamenco New York Times, 17 November, $\mathrm{p}$.

Schmitt, T. M. 2008. The UNESCO Concept of Safeguarding Intangible Cultural Heritage: Its Background and Marrakchi Roots. International Journal of Heritage Studies, 14(2), 95-111.

Seeger, A., 2009. Lessons learned from the ICTM (NGO) evaluation of nominations for the UNESCO Masterpieces of the Oral and Intangible Heritage of Humanity, 2001-5. In: Smith, L. and Akagawa, N. eds. Intangible Heritage. Oxon: Routledge, 112-128.

Sekimoto, T., 2000. Innovation, change and tradition in the batik industry. In: Hitchcock, M. and Nuryanti, W. eds. Building on Batik: the Globalization of a Craft Community. Burlington, USA Ashgate, 23-31.

Setyoningrum, Y., et al. 2015. Hierarchical social structure and the social spaces formation in traditional limasan house of Javanese middleclass society The International Journal of Social Sciences, 32(1), 37-45. 
Skounti, A., 2009. The authentic illusion: humanity's intangible cultural heritage, the Moroccan experience. In: Smith, L. and Akagawa, N. eds. Intangible Heritage. Oxon: Routledge, 74-92.

Smith, L., 2006. Uses of heritage. London, New York: Routledge.

Stefano, M. L., 2012. Safeguarding intangible cultural heritage. Woodbridge: Boydell Press.

Titchen, S. M. 1996. On the construction of 'outstanding universal value': Some comments on the implementation of the 1972 UNESCO World Heritage Convention. Conservation and Management of Archaeological Sites, 1(4), 235242.

Tunbridge, J. E., Ashworth, G. J. and Graham, B. J. 2013. Decennial reflections on A Geography of Heritage (2000). International Journal of Heritage Studies, 19(4), 365-372.

UNESCO, 1994. Expert Meeting on the 'Gobal Strategy' and thematic studies for a representative World Heritage List. Paris: UNESCO.

UNESCO, ed. Intergovernmental Conference on Cultural Policies for Development 30 March - 2 April 19981998 Stockholm, Sweden.

UNESCO, 2012. Representative list of the intangible cultural heritage of humanity. Paris: UNESCO, Sector for Culture.

Wahyudin, D., 2009. Batik: ikon cultural industry Indonesia. Paris: Kedutaan Besar Republik Indonesia-Paris.

World Commission for Culture and Development, 1996. Our creative diversity. Paris: UNESCO.

Yampolsky, P. 1995. Forces for change in the regional performing arts in Indonesia. Bijdragen Tot ed Taal-, Land-en Volkenkunde, 151(4e), 700-725.

\footnotetext{
${ }^{\mathrm{i}}$ See the UNESCO webpage for further information and examples of the UNESCO ICH domains (https://ich.unesco.org/en/1com).
}

${ }^{\text {ii }}$ Key moments in these discussions were the 2004 double issue of Museum International (volume 56 issue 1-2) on intangible cultural heritage that closely followed the ratification of the convention, two edited monographs that were published in the following years (Aikawa-Foure 2009, Stefano 2012), and now UNESCO and the CSICH have become a common focus or inclusion in heritage research (Harrison 2013, Alivizatou 2012).

iii These essays were first published on the Cultural Commons webpage, which has since been shut down, and were reprinted in Museum Anthropology Review in 2012.

${ }^{\text {iv }}$ My analysis of landscape towards the end of this paper requires an approach that focusses on the drivers and resistors to landscape change (Mitchell 2013, Barke and Parks 2016, Post 2013). This pushes my analysis more towards approaches that focus on such issues and tensions, in particular the realm of heritage (Ashworth and Tunbridge 2000), although it should be noted that contemporary themes of heritage, memory and multiplicity are often both framed by and address such transformations (Robertson 2015). Don Mitchell (2013, p. 219) writes: "The 
landscape-as-built-environment is a repository of values, both economic values and the sedimented values of culture." The landscape aspects of this work addresses itself to landscapeas-built environment in this sense in order to acknowledge changing batik neighbourhoods as an effect of the ICH program rather than seeking to understand the complex relationships of residents and others to these changes, which would be an excellent topic for another paper.

${ }^{v}$ Member states is the UNESCO term for nation-states that are members of UNESCO. They provided input through the UNESCO Executive Board meetings and the General Conferences.

${ }^{\text {vi }}$ Most notably the New World Information and Communication Order (NWICO) in the 1970s (Miller and Yudice 2002). The need for an agreement like the CSICH was reinforced by statements in the Our Creative Diversity report (World Commission for Culture and Development 1996), and the Intergovernmental Conference on Cultural Policies in Stockholm in 1998 (UNESCO 1998).

vii Another issue, much like the World Heritage Committee, is the overriding of expert advice by the state parties. Nominations that are not supported by expert advice are routinely admitted. This is a threat to the reputation of the lists, register and the CSICH.

viii In particular, the ACCU's Cultural Heritage Protection Cooperation Office (http://www.nara.accu.or.jp/english/).

${ }^{\mathrm{ix}}$ For more information on ICHCAP, see: http://www.ichcap.org.

${ }^{\mathrm{x}}$ Some nominations are withdrawn if difficulties emerge during the assessment. For instance, 45 applications remained (43 nominations and 2 applications for funding) from the initial 50 applications from the 2015 cycle were processed.

${ }^{x i}$ The reaction to the listing of the "gastronomic meal" is notable (Sayare 2010, Block 2010), although many commentators failed to realise that they were listing long lunches rather than French cuisine. Cullen Murphy (2001) in a well-cited article, made this point in the Atlantic Monthly in response to an Italian Minister's advocacy of pizza as Masterpiece of the Oral and Intangible Heritage of Humanity.

xii Transcribing was judged not to be necessary due to the historical rather than discursive approach pursued in this study. This necessitated the return to the recordings at the time of writing to ensure credibility (Lincoln and Guba 1985). I undertook all interviews in Indonesian with some English depending on the preference of the interviewee.

xiii A kris or keris is a traditional dagger with a record on Java back to the fourteenth century.

xiv The shift from a focus on the Representative List to the Urgent Safeguarding List follows a UNESCO directive that the latter list would receive a higher priority due to the initial focus on the Representative List, and the prioritisation on the Representative List of countries with no or few listed ICH. http://www.unesco.org/culture/ich/en/lists

${ }^{x v}$ The Coordinating Ministry for People's Welfare had the power to bring together different national departments on issues that required them to work together. Hence they are involved 
with the Directorate of Culture in every listing coordinating the different national departments, while the Directorate of Culture executes the tasks required for coordination and communication across-departments, UNESCO, lower levels of government and other organisations (NGOs, peak bodies and other organisations).

xvi The national list for Indonesian ICH became law in 2009 on the basis of a Joint Ministerial Decree of the Interior Minister and the Minister for Culture and Tourism (Peraturan Bersama Menteri Dalam Negeri dan Menteri Kebudayaan dan Pariwisata Nomor 42 Tahun 2009 dan Nomor 40 Tahun 2009 tentang Pedoman Pelestarian Kebudayaan).

${ }^{x v i i}$ For instance, Clark and Pietsch (2014, pp. 81-84) document how Malaysian batik producers both employ Indonesian batik artisans, and their employees travel to Central Java to study batik printing techniques.

xviii These two listings, coming one after the other, are a reminder of the nationalist Indonesian song, based on La Marseilles, Dari Sabang sampai Merauke. The municipality of Sabang is at the western point of Aceh, and Merauke is in the east of Papua.

${ }^{x i x}$ The full title is: Education and training in Indonesian Batik intangible cultural heritage for elementary, junior, senior, vocational school and polytechnic students, in collaboration with the Batik Museum in Pekalongan.

${ }^{\mathrm{xx}}$ A similar Forum was formed in Kauman in 2006. 